\title{
Which Alternative? A Critical Analysis of YouTube- Comments in Anti-Fascist Protest
}

\author{
Christina Neumayer
}

\author{
IT University of Copenhagen, Copenhagen, Denmark, chne@itu.dk
}

\begin{abstract}
This article examines the critical potential of YouTube-comments to foster the development of counter public (Negt and Kluge 1972). The argument is based on an analysis of YouTube-comments in anti-fascist protests taking place in East Germany in 2011. The comments represent political positions across the political spectrum and are analyzed as: [1] form of the comments; [2] different political positions as friend-enemy constellations; [3] the struggle for attention in the mass media; [4] the critical potential of the different alternatives represented in the comments. The article concludes with a discussion of the emancipative potential of social web platforms such as YouTube to support the struggle from below and to give voice to oppressed political positions.
\end{abstract}

Keywords: Critical Media, Protest, Counter Public, Hate Speech, Social Web, Radical Democracy

Acknowledgement: I want to thank Andrew Feenberg and Maria Bakardjieva for their valuable feedback on a draft version of this article presented in a PhD course at the IT University of Copenhagen, and Christian Fuchs and Göran Bolin for their comments at the Political Economy and Critical Theory of the Internet panel at NordMedia11.

Social web platforms such as YouTube, Facebook or Twitter are frequently associated with an emancipative potential and thus, with deliberation, participation and grassroots action. The uprisings in Egypt, the Iranian elections or the campaign of Barack Obama are some of the recent examples for the role of the social web for political action. However, the web also provides spaces for right-wing groups, fascism or terrorist groups, who use information and communication technologies effectively to spread their political perspectives. As a recent study shows right wing populism in the social web is increasing all over Europe (Bartlett, Birdwell, and Littler 2011). The anti-fascist protests in East Germany are a physical representation of confrontation between groups from the far left and right end of politics. Although many authors would claim that the display of heterogeneity of conflicting viewpoints is beneficial for democracy and freedom of speech (Barber 1984; Mouffe 2005; Pateman 1970) there is uncertainty about how to deal with right wing speech (see for example Cammaerts 2009). The representation of the confrontation in the anti-fascist protests online includes political positions throughout the political spectrum, i.e. different alternative positions that oppose the mainstream discourse in the institutionalized mass media.

There is a range of studies available that deal with progressive movements and alternative political perspectives on the web (see for example: Mattoni 2008; McCurdy 2009; Uldam 2010; Lester and Hutchins 2009). These studies discuss the relationship between mass media, alternative online media and social movements. However, they usually refer to social movements with an agenda to foster social change, the protection of the environment or criticize globalization and capitalism. Concepts that include a discussion of radical right-wing positions as an alternative to the mainstream are the alternative Internet (Atton 2004), radical media (Downing et al. 2001) or counter public (Brouwer 2006; Fraser 1992). Most of these concepts focus on the modes of production in digital media as an alternative to the mainstream, i.e. collaboratively produced user-generated media content. The participation of the radical right in these forms of digital media is a normal consequence. Dahlberg (2007) argues from a post-Marxist discourse theory perspective that likeminded groups outside of the mainstream are part of the political but often stay within their fragmented publics. In the event discussed in this article different political perspectives are confronted with each other but also enter the public discourse and gain attention by the mass media.

This article is based on an analysis YouTube-comments about anti-fascist protests in East Germany, i.e. an event where radical right and left-wing-groups are confronted with each other and the social web plays an important role. It discusses the role of alternative media by analyzing comments that represent political positions throughout the political spectrum. Using the concept of counter public (Negt and Kluge 1972) in relationship to class and propaganda within a post-Marxist discourse theory framework (Laclau and Mouffe 1985; Mouffe 2005), this article investigates the 
critical potential of YouTube-comments to give a voice to the oppressed in their struggle from below.

\section{Public, Counter Public and Critical Media}

From the perspective of radical democracy theory (Laclau and Mouffe 1985; Mouffe 2005; Dahlberg 2007) counter-discourses have to be studied as both counter public and discursive contestation, i.e. including inter- and intra-discursive contestation, that are all part of "the political". Fairclough $(2003,3)$ uses the term discourse in a very broad sense "as an element of social life which is closely interconnected with other elements". Within his framework a discourse is a way of representing certain aspects of the world in texts, including visual images and sound. The discourses of the groups studied in this article are based on political ideology, i.e. representations that can contribute to power and domination (Fairclough 2003, 9). The textual representations of ideology are one form of reproducing power and domination. Chouliaraki $(2008,26)$ argues that studying representation of ideology in discourse also means an analysis of "mediated action within a specific space and time that separates 'us' from 'them'". The separation between them and us in friend-enemy constellations in discourse become apparent in the case studied in this article since two political perspectives are in conflict with each other.

Activists usually try to challenge existing power relations what requires the development of a political community and the identification of an enemy. In Mouffe's (2005) concept of agonism the enemy is rather an adversary that does not have to be eliminated. The expected outcome of the construction of these friend-enemy relationships is what Mouffe calls conflictual consensus. To consider enemies rather as an adversary whose opinion is respected and critically evaluated in discussion is the ideal form of democratic pluralism (Laclau and Mouffe 1985).

Since the events discussed here get attention by the mass media, they also have to be put into perspective as potential counter discourses to the mainstream. As Cammaerts and Carpentier (2009) argue in a study about blogging activists, the distinction between hegemonic and "potentially counter-hegemonic" positions cannot be clearly drawn anymore. The relationship between mass media coverage, radical media and representation on websites and in social media are crucial and hard to distinguish from each other. Consequently, a dualistic perspective is not adequate in order to understand the relationship of digital and mass media in protest but the relationship between different media formats becomes a relevant criterion for political communication online.

To adopt a frame for collective action, what is required in the anti-fascist protests, includes the incorporation of political consciousness of individuals. The individual level is linked to the sociocultural level by mobilizing acts in face-to-face situations of interpersonal communication or mass mobilization (Gamson 1992, 187). Nowadays, these interpersonal encounters can also be carried out online in political forums, websites, blogs or social web tools such as micro blogging, digital social networks or commenting on YouTube. These individual preferences do not erase the necessity of collective identity but work dialectically on a meta- and micro-level. In the case studied here these individual encounters reflected in discussion on YouTube are part of the development of social realities that are constructed along historically grounded political beliefs.

The technologies activists use to articulate alternative political positions are not neutral but shaped by social and political interests implicit in technology design (Winner 1986; Feenberg 2010). Developed based on capitalist interests, information and communication technologies support existing class bias and capitalist power. According to Feenberg (2010), technology can be used for both sustaining existing hierarchies and dominant positions and to challenge or circumvent these hierarchies by struggle. To use the emancipative potential of the Internet to challenge domination is dependent on practices of individuals. From this perspective the use of technology is dependent on the political believes of certain groups or as Turner (2006) argues the political, historical and cultural context of certain communities is reflected in their media, i.e. in the meaning of technological objects. By their alternative sets of values and beliefs, users of these technological systems can address needs that are ignored by the mainstream development of technologies (Bakardjieva 2005, 19).

However, this alternative use of technology is dependent on the intentions, political values, and beliefs of the groups who employ different platforms to construct their alternative political perspectives. Concepts that describe alternative media are often based on the production process and consequently include far right and left wing alternatives alike. In contrast Negt and Kluge's (1972) concept of counter public is based on the proletarian public. The development of counter publics from their perspective is based on class struggle from the proletariat. This idea stresses the importance of the expression of counter-ideas by the political left. Negt and Kluge highlight that counter-publics only produce their own realities as a counter-position to the bourgeois society if they 
also have the opportunity to act. This concept differs from contemporary readings of counterpublics (e.g. Brouwer 2006; Fraser 1992) that also include radical right perspectives, whereas for Negt and Kluge only left wing publics can be counter-publics by definition.

Fuchs' (2010a) concept of critical media is based on counter publics according to Negt and Kluge. He argues that critical media are characterized by their form but also content. They provide alternatives to dominant repressive perspectives such as capital, patriarchy, racism or nationalism; challenge domination, provide counter information and give a voice to the excluded. They should express what a society could become and not only discuss what it is right now. Critical media question structures of exploitation and thus, provide a base for social struggle. From this perspective the question if social web content is critical depends not only on the current state of a group or community but also on the alternative society they suggest.

The concept of counter public is based on the proletarian public. In a discussion about class in informational capitalism, Fuchs $(2010 \mathrm{~b}, 193)$ uses the example of voters for right-wing extremist parties who support the reproduction of racist classes by degrading immigrant workers' class position to improve their own position in society. He argues that class is still dominant in informational capitalism, but that different groups such as for example immigrants constitute the working class. In An Essay on Liberation, Marcuse $(1969,50 f)$ argues that the seemingly free life that is constructed in capitalist society and at the same time the increasing struggle for existence due to economic pressure produces aggressiveness. Due to false needs and false consciousness of consumption, the victims of domination repress alternatives to the repressive society they live in. The aggressiveness against groups that are different is the actual aggressiveness of the Establishment, i.e. the dominant groups.

Social web platforms do not necessarily offer spaces for articulation of alternative perspectives that challenge mass-mediated discourse, but can also strengthen dominant political positions. As several studies show, activists have strategies at hand to enter the public discourse with the help of online platforms (Lester and Hutchins 2009; Rucht 2004). At the same time Daniels (2009) in her study about propaganda and cyber-racism on cloaked websites shows evidence for propaganda, advertising, politics, and cyber-racism to converge, which makes it harder to differentiate between civil rights websites and racist sites. Consequently, a hidden racist, nationalist and manipulative agenda can be much more effective than outspoken racism and far right-wing politics. Herman and Chomsky's (2002) propaganda model can explain these hidden meanings. In their updated version of Manufacturing Consent they add the production of fear as an additional filter in the news media to their propaganda model. Fear is used strategically to produce hate and aggressiveness upon a certain group of people. From a critical political economy perspective, an analysis of propaganda starts with the analysis of the powerful that dominate the information flow and do not provide space for contesting parties and thus for counter publics to emerge (Herman and Chomsky 2002, 108).

In an analysis of far right websites, Atton (2006) describes how the discourse of alternative progressive movements is used to maintain the oppressive ideological space of right-wing groups. The occurrence of right wing and racist discourse challenges the limits of freedom of speech and of radical pluralism (Cammaerts 2009). Morozov (2011) concludes in his analysis of the two-sided results of Internet freedom in authoritarian regimes that technology cannot solve humanity's problems but could decrease their visibility. Decentralization even makes it easier to include the desired ideas into national conversation to the same advantages that can foster ad-hoc organization of progressive movements, i.e. advantages in overcoming space and time with limited costs. From this perspective the voices that become visible in online communication as part of what constitutes the political (Mouffe 2005) are diverse. Not all of the antagonisms that are represented can result in agonism as described by Laclau and Mouffe (1985), i.e. conflictual contestation that can be constructive if groups show respect for each other in discussions within friend-enemy constellations.

To sum up, the following characteristics help to understand the case studied in this article, i.e. the critical potential of YouTube-comments in anti-fascist protests:

1. The basic form of the comments (e.g. number, word frequencies) and the relationship between the authors;

2. different forms of friend-enemy constellations that help to understand the different positions represented in the political and the power relations between them;

3. the struggle for attention in the mass media that can he analyzed with the help of the concept of the counter public as an alternative to the mainstream;

4. the struggle against right-wing speech that helps examining the critical potential of YouTubecomments. Along these lines the YouTube-comments in anti-fascist protests will be examined in order to analyze the potential of social web platforms such as YouTube as critical media. 


\section{Anti-Fascist Protests: A Brief Case Description}

Since 2009, especially Dresden, the capital of Saxony, has played an important role in the discussion of German right-wing politics from a political, legal, and social perspective. The march by Neo-Nazis that took place for the third time on February 13 (and in 2011 also on February 19), a memorial day remembering the Dresden-bombing in World War II, was accompanied by huge blockades organized by anti-fascist groups, NGOs and civil society. In 2011 approximately 2000 Neo-Nazis (compared to 6000 in 2010) participated in the march, opposed by about 20000 counter-protesters involved in blockades. The possibilities offered by new communication tools such as micro blogging, blogs, digital social networks, Google maps, smart phones, and laptops played an important role, especially in mobilization and coordination of the counter-protest. Compared to the years before, the event also gained attention by mostly regional but also national mass media and has started to be part of the societal discourse in general. An important part of the still ongoing public discussion is why radical right wing groups use the democratic right of freedom of expression to justify their march.

From a historical perspective, memorial days, parades, and marches have been an important element of fascist propaganda to demonstrate power (Benjamin 1936). Relevant themes that framed the history of the Nazi-regime's capture of power are war, racism, violence, and order (Bessel 2004, 187). These themes are still reflected in the discourse of far right wing groups online. On the contrary, as Karner (2007) concludes in his analysis of Austrian counter-hegemony, anti-fascist discourse evolves around three thematic areas: counter-hegemonic alternatives to ethnic or national identity and exclusion, resistance to challenge racism, and criticism to neo-liberalism and economic globalization. In the comments on YouTube, these themes are discussed in confrontation between the opposing political positions.

\section{A Short Note on Methodology}

According to Rogers (2009), the Internet itself is "a site of data about society and culture" and, consequently, claims about radical political positions can be grounded online. Taking this groundedness in digital media data as a point of departure, I use the conceptual framework of discourse analysis (Fairclough 2010; Chouliaraki 2008; van Dijk 2001) to identify the different political positions that are part of the construction of the social realities of the different political groups in the comments on YouTube. According to van Dijk (2001), the role of political discourse is enactment, reproduction, and legitimization of power and domination. Fairclough $(2003,127)$ argues that texts about the same event differ from each other because they are embedded in social practices that represent the discourses they draw upon. The comments are analyzed along these lines to investigate the critical potential of commenting on YouTube within the different political perspectives represented in the comments about the anti-fascist protest.

The following chapters are presented as described in the theoretical framework: [1] form and frequencies of the comments, [2] different forms of friend-enemy constellations, [3] the comments as an alternative to the mainstream, [4] the comments as a critical alternative.

The analysis is based on YouTube-comments posted as a response to a video published in the anti-fascist protest on February 19. The comments are part of a bigger dataset of online communication in anti-fascist protests. 3337 comments posted between February 19 and July 19, 2011, were included in the dataset, also those that were flagged as spam. The video under examination shows radical right-wing groups smashing the windows of a house by throwing stones. The house is known as an alternative living project in Dresden and was already target of violence by radical right-wing groups in 2010. The length of the video is 2 minutes and 47 seconds and it shows how activists attack the house. After 30 seconds the camera turns to two police cars, the police officers watching the events. Then the camera turns back to the action. The video is accompanied by a short message that was posted under the video. In the message, the author asks for distribution of the video to show that the police did not interrupt the violent action while trying to repress the blockades against the Neo-Nazi marches.

In general, YouTube was used by both parties involved in the protest to distribute mobilizationclips, to transmit videos to mass media, and to post user-generated videos taken on mobile phones to show alternative perspectives. The video discussed here was taken on a mobile phone, i.e. represents the modes of production advocated as citizen journalism. The link to the video is the most frequent reference to YouTube on Twitter about the anti-fascist protests. The video was viewed 118708 times at the end of the time-period, in which the comments were collected. The comments 
were exported into an Excel-sheet including date, author, and recipient (if applicable). The open source software Yoshicoder was used to count word frequencies and frequency of authors and recipients. For further qualitative analysis the open source software TAMS analyzer was used.

\subsection{Form and Frequencies}

The 3337 comments were posted in a time-span between February 19, 2011, and June 19, 2011. The video was posted on February 19 , which was the day of action for the anti-fascist blockades in Dresden. 123 comments were flagged as spam by other users, which means that they are not immediately visible on the YouTube website, but can be accessed by clicking on a link. Although many of the comments include hate speech or references to National Socialism only 18 comments were totally removed and cannot be accessed anymore.

Counting word frequencies of all individual words in the comments, including those marked as spam, words such as "you"1 (in the German singular and plural form) and "l" were most frequently used. After exclusion of articles, clauses, personal pronouns, and modal verbs, the most frequently used word in the dataset is "Nazis", followed by "the left" (noun, plural), "left" (adjective), "people" and "police". These words represent the different groups in the discussion, i.e. the friend-enemy constellations discussed in the next section of this article.

The 3337 comments were posted from 678 different user-accounts. 432 of these users only posted one comment, 106 two comments, and only 35 of the participants in the discussion posted more than 10 comments. The user who participated most actively in the discussion posted 802 comments, the second most active participant in the discussion posted 432 comments in total. The user who posted most of the comments is according to the account profile generally active on YouTube. The content published on the channel of this user can be described as nationalist, implicitly racist, and the self-description of the user includes criticism to left-wing parties and anti-fascists. The account with the second most comments was closed down by the user and does not exist anymore.

2368 of the comments have a specific addressee, i.e. are a response to another user's comment. Not surprising the user who posted most of the comments also received most of the responses (468), followed by the user who posted the second most comments (457). The two users have confronting political perspectives and many of their comments are an interpersonal discussion, sometimes commented by other participants, over a longer period of time.

The centrality of a few users in the YouTube-comments is a tendency that can also be observed on other social web-platforms (see for example: Bruns et al. 2010; van Zoonen et al. 2011), where a few core-participants dominate the discussion. The interpersonal communication in this example can also be seen as an example of what Bakardjieva (2009) describes as subactivism, individual encounters between citizens on digital media platforms that are part of the democratic potential of the Internet, but lack bridges to the public. However, these individual encounters do not necessarily lead to deliberation or have a critical potential that can support class struggle as Negt and Kluge (1972) describe in their concept of counter public.

\subsection{Friend-Enemy Constellations}

Since the video shows violent action, violence is also an important element of the discussion in the comments. The friend-enemy constellations in the comments represent the different political positions of the participants in the discussion. Violence is often a key element of newsworthiness in media reports about protest, inserted into a larger narrative in a decontextualized manner (Juris 2005). The main critique found in the comments about the video discussed here is that the police watched the events without acting or helping the people in the house being attacked by Neo-Nazis. At the same time, the comments stress that the police were using violence against the activists involved in the blockades, a circumstance that was also criticized by the NGO Amnesty International after the events (see Amnesty International 2011). As already shown by word frequency counting, the police were also considered as main actors apart from the two conflicting parties.

The different positions represented in the comments are also reflected in the discussants' position to the video. The video produces an alternative perspective to the mass media coverage about the events. At the same, time representatives from the right-wing spectrum question the credibility of the video:

What happened before? I read that someone threw firecrackers out of the house. Do you want to question that or would you even consider that?

\footnotetext{
${ }^{1}$ All comments are originally in German and translated by the author.
} 
Have you seen that a Nazi posted your video again and said that left anarchists attacked the $X X$ ? Can you do something against that?

Although video is one of the most persuasive methods to document activities compared to written statements, it is subject to criticism and doubt in terms of credibility, i.e. what it documents and what information it deliberately leaves out. Another strategy to question the credibility of the video is authorship. The video also shows up under the name of a different author and is used to support radical right political positions by claiming that it was anarchists who attacked the building. This second use of the video only got limited attention, i.e. only 290 views. However, the question of credibility is an important one and the strategy of changing the meaning of the video suggests that user-generated "news" and "truth" are not necessarily the same, even though they claim to be so as a counterpart to mass mediated content. The different political positions represented in the comments change the meaning of the video according to the social realities the different groups construct. The video can be a powerful tool to contest mass mediated meaning, but the different political positions influence the interpretation of the video. Consequently, the video supports the construction of different social realities according to the interpretation, framed by the different political positions.

The ambiguity of reporting from protest events with the help of video-material is also questioned in terms of privacy and "real" identity of the actors portrayed in the video:

Who is the guy who recorded this on the mobile phone?? If it was one of your people, tell him that these things shouldn't be recorded! The police can use this as evidence!!! [...]

Using a mobile phone to record events in protest could be used as evidence by the police and consequently increases the potential repression against activists involved in civil disobedience and especially violent action. Videos and pictures taken on mobile phones can reveal the identity of activists and police alike and be a strategic weapon. The video can also be used as a tool of repression by authorities and can thereby strengthen existing power relations.

Readiness to act violently is seen as an important aspect of identification with a specific group and as an expression of difference:

Generally I do not support violence at all ... but I do agree that violence can be used against fascist propaganda if no innocent people are harmed. [...]

Stupid right and left extremist mob! Just beat each other up, but leave us [citizens] alone!

By discussing violent action in protests, different political positions represented in the comments become apparent. Violence is usually justified if directed to the opposing group in the conflict and accepted as a legitimate source of activism. Participants in the discussion, who describe themselves as citizens, do usually not support violent action although they support the political cause of the blockades. Violence is thus used to differentiate core-activists from civil society that supports the cause of the blockades and may engage in civil disobedience but not in violent action. At the same time activists involved in the blockades question their own political liability by mobilizing groups throughout the political spectrum for the protest but loosing a clear left-wing political message. The construction of alliances supports the blockades and strengthens their counterhegemonic articulations but that also creates the risk of dispersion (see also Uldam 2010, 72). The dichotomy created by the political cause, i.e. supporting the march by the Neo-Nazis or the counter protest, is frequently questioned:

[...] There is neither 'the left' nor 'the right'. Because left starts already with the political parties in the parliament and they really don't beat anyone up... The same with the right [...]

A bipolar division between left and right is insufficient when mapping the different political positions in the discussion. Since the content of the video is violent action the discussion evolves around this issue, also as an element to represent political positions. Activists use violence and civil disobedience to radicalize political positions and to challenge domination. On the contrary, the police use violence to repress blockades, to protect the Neo-Nazi march and to maintain domination by authority. It is dependent on the political position of the recipients if they interpret the video as evidence to prove violent action by the Neo-Nazis and failure of the police in interrupting them or as a video lacking credibility.

\subsection{Contesting the Mainstream}

Publishing user-generated content on social web platforms in order to create an alternative perspective to the mainstream in mass-mediated discourse is a common strategy in activism (Lester and Hutchins 2009; McCurdy 2009). YouTube videos can strategically be used to challenge the representation of activists in news media reports. Social web platforms in general give activists the possibility to comment on their portrayal in the mass media, often criticizing it as inappropriate and one-sided. The YouTube videos are thus used to contest the image created in mainstream media: 
Media already cover this topic (the failure of the police). However, I am afraid it will not be more than a side note.

The video indeed was integrated into reports of mass media, but as criticized in this comment, the behaviour of the police was only marginally questioned. Mass media used the video to create a violent image of activists throughout the political spectrum. No difference is in such representations drawn between Neo-Nazis and anti-fascists; both are depicted as violent and chaotic.

In the comments not only the relationship with mass media but also other media outlets were discussed. News media sources, encyclopaedias, Wikipedia, or websites, were used to support arguments:

What's that? XX has almost published a novel, unfortunately only with the level of information of the [name of German tabloid]. [...]

Just a moment, a mainstream media is rather left because the mainstream is rather left? By the way Wikipedia is absolutely transparent, the old versions on the site are still online and visible if you believe in 'conspiracy'. [...]

Although mass media articles, websites, and encyclopaedias are often used as a frame of reference, they are also questioned according to the political position they represent. The participants in the discussion are aware of the quality levels of certain newspapers and discuss such circumstances in the arguments they make. Sources are also criticized because of their political bias, e.g. Wikipedia as left leaning due to its decentralized production process. In the references to alternative media, the different realities of the groups become even more apparent:

[...] The media are liars and occupied by the left wing. So what can you expect apart from propaganda? If you don't believe me, look up a document called "Lies against right-wing" on the Net. It is a pdf-file and for free.

[...] Or do you look up Indymedia every day and think that they report about the truth? [...]

These comments support the assumption that there is a fragmentation of different political positions on the social web (Dahlberg 2007). As Wojciezack (2010) argues, dissimilar ties exacerbate political perspectives that are formed in online and offline groups. The opponent's media outlets and the mainstream media are considered as being not trustworthy and liars throughout the comments. This supports the political position of the groups in confrontation. Consequently, the YouTube video does both: maintain the dominant frame in the mainstream media by being adapted in a decontextualized narrative or contest it depending on the frame for interpretation.

\subsection{Which Alternatives?}

As the YouTube-comments discussed here show, the emancipative potential of the web can give a voice to alternative political positions. However, the question remains if the perspectives represented in the comments are critical and can contribute to contestation and struggle of the proletarian public (Negt and Kluge 1972) or if they rather support domination and the distribution of propaganda. There were not only progressive comments but also anti-democratic ones. The alternative society suggested by the right-wing comments is based on fear, domination and racism. The German nation is described as superior, a place to fight for and to be protected. On the contrary, anti-fascists are portrayed in the comments posted by participants of the far right political spectrum as being against everything, increasing instability and challenging existing systems:

How can a movement be good and anti-fascist, if it is against everything established, functioning, ruling and thus, an element of objective destruction, that has a dangerous meaning for the nation $[. .$.

The radical right questions the struggle against existing power relations and domination as disrupting security, stability and clear structures. The nation is presented as superior to foreign influence, and it is argued that "disruptive" forces could threaten German domination.

In the same way as the marches themselves are justified, the rhetoric of freedom and democracy is used in the comments to justify actions of the right-wing groups. The question why they are able to use freedom of expression, a fundamental democratic right, to legitimize their action and why this is supported by legal decisions has also been an important issue in the public discussions about the events. The relationship between authorities and the Neo-Nazis and the criticism to legal decisions in relationship to the marches are also expressed by the relationship between police and different activist groups:

German police help fascists. You copy our clothes, our symbols; you don't even have your own ideas. [...]

The police are often presented as an ally of the Neo-Nazis since they protect the fascist march and try to repress the blockades of anti-fascists. The blockades are an act of civil disobedience 
from the perspective of the Neo-Nazis and the police, but struggle against the fascists, authorities and the establishment from the anti-fascists' view.

Right-wing speech in the comments becomes apparent in the discussion of racism and in direct references to National Socialism. "Foreign domination" is presented as a threat to German dominance and this attitude is expressed in racist comments and xenophobic expressions:

Yes, I feel very bad and awful and project that on the poor foreigners because those who are against foreign domination are bad foreigner-hating fascists. Buhuhu. Wait until my "xenophobia" is justified. But then when the mob here really freaks out [...]

Adolf Hitler cannot be replaced and his deeds shall not be forgotten! Now it is us who have to continue his great work! [...] Heil Hitler! You are among us! [marked as spam]

Although a user marked the second comment as spam it can still be accessed and was not removed. Direct references to the national-socialist regime and racism are clearly not a desirable alternative. Authoritarian, nationalist and racist speech is a direct threat to democracy and in this example questions the role of the YouTube comments as critical media.

\section{Conclusion}

As the YouTube-comments show, the Internet has an emancipative potential and can foster grassroots struggle. However, as Feenberg $(2010,6)$ argues, technologies have to be used in a certain way to foster social and political change, i.e. free from the power relations reflected in the use of technology. The power relations that are present in the anti-fascist protests (between mass media and critical perspectives, between authority, anti-fascists and civil society engaged in the blockades, and between Neo-Nazis and anti-fascists) can be potentially challenged by social media, but are also maintained with the help of them. This becomes especially evident in the relationship between mass media coverage and the YouTube-video. Although the video actually shows failures of the police and violent action by radical-right wing groups, it was also used in a decontextualized manner to support the frame of violent activists in news media coverage and thus the power of the mainstream.

To return to the question weather the YouTube-comments can be considered as critical media (Fuchs 2010a) based on the concept of the counter public by Negt and Kluge (1972), not only the modes of production have to be taken into account but also the content of the comments, i.e. the alternative they suggest and what a society ought to be rather than what it is. From this perspective, the alternative offered by the right wing can certainly not be considered as critical, challenging existing power relations and contesting class structures. They suggest a fascist and undemocratic alternative that enforces class structures. The alternative that the fascists imagine is a nationalist regime that is dominated by an elite that exterminates opponents and minorities. Fuchs (2010b) describes minorities such as immigrants as part of the proletariat in informational capitalism. The aggressiveness against minority groups can according to Marcuse (1969) also be described as aggressiveness of the establishment. These voices from the establishment can consequently, not be considered as critical within Negt and Kluge's framework that refers to the struggle by the proletarian public. Although some of the comments support the struggle of the anti-fascists, provide a critical potential and stress, that the aim of the video originally was to contest domination by providing prove for the police's problematic behaviour, the outcome reflected in the comments did not serve this purpose. The question remains how to deal with racist and hate speech on the web from a policy perspective. Cammaerts $(2009,570)$ argues that silencing these voices by filtering does not necessarily fight their symptoms or erase them from the political since they would find other spaces to express their positions online.

The comments on YouTube indicate that neither a functionalist nor a solely techno-determinist perspective is adequate to describe the relationship between the social web and political contestation. The functionalist perspective suggests that technology is simply a tool that does not have any impact on grassroots action but serves the political group or individual and thus, the political position of the user. The video itself, however, represents a way of contestation that was not possible before, i.e. showing the perspective of activists on behaviour of the police and Neo-Nazis. The techno-determinist perspective suggests that the invention of a new technology changes society and political contestation. This perspective is also not supported by the observation made in the YouTube comments since the different political positions are clearly reflected in the discussion.

Consequently, it is important to understand the way the social web changes different forms of contestation in context but including the political positions as part of the alternatives presented. Since social web platforms such as YouTube provide space for progressive movements, but also for right-wing propaganda and hate speech, these platforms have to be critically assessed according to their potential to enhance grassroots action and to give a voice to the oppressed. The eman- 
cipative potential of technology that Feenberg describes cannot be realized if technologies are used for undemocratic purposes and to foster power relations that are reflected in the use of the technology. To potentially support social change alternative media have to allow critical discourse.

\section{References}

Amnesty International. 2011. Nicht nur für Sachsen: Lehren für die Zukunft nach Polizeieinsatz bei Anti-Nazi-Protesten in Dresden. Accessed February 23, 2011. http://www.amnestypolizei.de

Atton, Chris. 2004. An Alternative Internet. Edinburgh: Edinburgh University Press.

Atton, Chris. 2006. Far-Right Media on the Internet: Culture, Discourse and Power. New Media \& Society 8 (4): 573-587.

Bakardjieva, Maria. 2005. Internet Society: The Internet in Everyday Life. London: Sage.

Bakardjieva, Maria. 2009. Subactivism: Lifeworld and Politics in the Age of the Internet. The Information Society 25 (2): 91 104.

Barber, Benjamin. 1984. Strong Democracy: Participatory Politics for a New Age. Berkeley: University of Berkeley Press.

Bartlett, Jamie, Jonathan Birdwell, and Mark Littler. 2011. The New Face of Digital Populism. Accessed January 25, 2012. http://www.demos.co.uk/publications/thenewfaceofdigitalpopulism

Benjamin, Walter. 1936. The Work of Art in the Age of Mechanical Reproduction. Accessed January 25, 2012. http://www.marxists.org/reference/subject/philosophy/works/ge/benjamin.htm

Bessel, Richard. 2004. The Nazi Capture of Power. Journal of Contemporary History 39 (2): 169-188.

Brouwer, Daniel C. 2006. Communication as Counterpublic. In Communication as ... Perspectives on Theory, edited by Gregory J. Shepherd, Jeffrey St. John, and Ted Striphas, 171-177. London: Sage.

Bruns, Axel, Jean Burgess, Tim Highfield, Lars Kirchhoff, and Thomas Nicolai. 2010. Mapping the Australian Networked Public Sphere. Social Science Computer Review 29 (3): 277-287.

Cammaerts, Bart. 2009. Radical Pluralism and Free Speech in Online Public Spaces: The Case of North Belgian Extreme Right Discourses. International Journal of Cultural Studies 12 (6): 555-575.

Cammaerts, Bart, and Nico Carpentier. 2009. Challenging the Ideological Model of War and Mainstream Journalism? Observatorio $\left(O B S^{*}\right)$ 9: 1-23.

Chouliaraki, Lilie. 2008. Discourse Analysis. In The SAGE Handbook of Cultural Analysis, edited by Tony Bennett and John Frow, 674-698. London: Sage.

Dahlberg, Lincoln. 2007. Rethinking the Fragmentation of Cyberpublic: From Consensus to Contestation. New Media \& Society 9 (5): $827-847$.

Daniels, Jessie. 2009. Cloaked Websites: Propaganda, Cyber-Racism and Epistemology in the Digital Era. New Media \& Society 11 (5): 659-683.

van Dijk, Teun. 2001. Critical Discourse Analysis. In Handbook of Discourse Analysis, edited by Deborah Tannen, Deborah Schiffrin, and Heidi Hamilton, 352-371. Oxford: Blackwell.

Downing, John D.H., Ford Villarreal, Genéva Gil, and Laura Stein. 2001. Radical Media: Rebellious Communication and Social Movements. Thousand Oaks: Sage.

Fairclough, Norman. 2003. Analysing Discourse: Textual Analysis for Social Research. London: Routledge.

Fairclough, Norman. 2010. Critical Discourse Analysis: The Critical Study of Language. 2nd ed. London: Longman Applied Linguistics.

Feenberg, Andrew. 2010. Between Reason and Experience: Essays in Technology and Modernity. Cambridge: MIT Press.

Fraser, Nancy. 1992. Rethinking the Public Sphere: A Contribution to the Critique of Actually Existing Democracy. In Habermas and the Public Sphere, edited by Craig Calhoun, 109-142. Cambridge: MIT Press.

Fuchs, Christian. 2010a. Alternative Media as Critical Media. European Journal of Social Theory 13 (2): 173-192.

Fuchs, Christian. 2010b. Labor in Informational Capitalism and on the Internet. The Information Society 26 (3): 179-196.

Gamson, William A. 1992. The Social Psychology of Collective Action. In Social Movements, edited by Jeff Goodwin and James M. Jasper, 168-187. London: Routledge.

Herman, Edward, and Noam Chomsky. 2002. Manufacturing Consent: The Political Economy of the Mass Media. Updated ed. New York: Pantheon Books.

Juris, Jeffrey S. 2005. Violence Performed and Imagined: Militant Action, the Black Bloc and the Mass Media in Genoa. Critique of Anthropology 25 (4): 413-432.

Karner, Christian. 2007. Austrian Counter-Hegemony: Critiquing Ethnic Exclusion and Globalization. Ethnicities 7 (1): $82-$ 115.

Laclau, Ernesto, and Chantal Mouffe. 1985. Hegemony and Socialist Strategy. 2001st ed. London: Verso.

Lester, Libby, and Brett Hutchins. 2009. Power Games: Environmental Protest, News Media and the Internet. Media, Culture \& Society 31 (4): 579-595.

Marcuse, Herbert. 1969. An Essay on Liberation. Boston: Beacon Press.

Mattoni, Alice. 2008. ICTs in National and Transnational Mobilizations. tripleC - Cognition, Communication, Co-operation: Open Access Journal for a Global Sustainable Information Society 6 (2): 105-124. Accessed January 25, 2012. http://triple-c.at/index.php/tripleC/article/view/82/75

McCurdy, Patrick. 2009. "I Predict a Riot" - Mediation and Political Contention: Dissent!'s Media Practices at the 2005 Gleneagles G8 Summit: LSE Theses Online. Accessed January 25, 2012. http://etheses.Ise.ac.uk/5

Morozov, Evgeny. 2011. The Net Delusion: How Not to Liberate the World. New York: Public Affairs.

Mouffe, Chantal. 2005. On The Political. London: Routledge.

Negt, Oskar, and Alexander Kluge. 1972. Öffentlichkeit und Erfahrung: Zur Organisationsanalyse von bürgerlicher und proletarischer Öffentlichkeit. Frankfurt am Main: Suhrkamp.

Pateman, Carole. 1970. Participation and Democratic Theory. Cambridge: Cambridge University Press.

Rogers, Richard. 2009. The End of the Virtual: Digital Methods. Amsterdam: Vossiuspers UvA.

Rucht, Dieter. 2004. The Quadruple "A": Media Strategies of Protest Movements Since the 1960s. In Cyberprotest: New Media, Citizens and Social Movements, edited by Wim van de Donk, Brian D. Loader, and Dieter Rucht, 29-56. London: Routledge. 
Turner, Fred. 2006. From Counterculture to Cyberculture: Stewart Brand, the Whole Earth Network, and the Rise of Digital Utopianism. Chicago: The University of Chicago Press.

Uldam, Julie. 2010. Fickle Commitment: Fostering Political Engagement in "the Flighty World of Online Activism". Copenhagen: $\mathrm{PhD}$ Thesis at Copenhagen Business School.

Winner, Langdon. 1986. Do Artifacts Have Politics? In Technology and Society: Building Our Sociotechnical Future, edited by Deborah G. Johnson and Jameson M. Wetmore, 209-226. 2009th ed. Cambridge: MIT Press.

Wojcieszak, Magdalena. 2010. 'Don't Talk to Me': Effects of Ideologically Homogeneous Online Groups and Politically Dissimilar Offline Ties on Extremism. New Media \& Society 12 (4): 637-655.

van Zoonen, Liesbet, Farida Vis, and Sabina Mihelj. 2011. YouTube Interactions Between Agonism, Antagonism and Dialogue: Video Responses to the Anti-Islam Film Fitna. New Media \& Society 13 (8): 1283-1300.

\section{About the Author}

\section{Christina Neumayer}

is a PhD student in the Design, Culture, Mobility and Communication (DCMC) research group at the IT University of Copenhagen. Her PhD project explores how radical political ideology is reproduced in digital media. Her research interests include activism, participation and political communication online. 